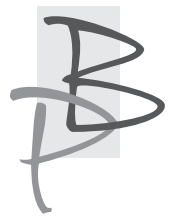

\title{
Łukasz Zabielski*
}

Dział Naukowy Książnicy Podlaskiej im. Łukasza Górnickiego https://orcid.org/0000-0001-5119-4835

\section{„Mickiewicz i romantycy wobec kultur wschodniosłowiańskich" - Międzynarodowa Konferencja Naukowa, Grodno 31 maja - 1 czerwca 2019 roku. Sprawozdanie}

W dniach 31 maja - 1 czerwca obradowała w Grodnie na Białorusi I Międzynarodowa Konferencja Naukowa „Mickiewicz i romantycy wobec kultur wschodniosłowiańskich”, inaugurująca polsko-białoruski cykl badawczy „Mickiewicz i kultury” (spotkanie kolejne zaplanowano w 2020 roku w Polsce). Jego koordynatorami są Katedra Badań Filologicznych „Wschód - Zachód" z Wydziału Filologicznego Uniwersytetu w Białymstoku, Katedra Języków Obcych Grodzieńskiego Państwowego Uniwersytetu im. Janki Kupały, Dział Naukowy Książnicy Podlaskiej im. Łukasza Górnickiego, Międzynarodowy Instytut Adama Mickiewicza w Grodnie oraz Biblioteka Uniwersytetu Grodzieńskiego ${ }^{1}$. Głównymi organizatorami sesji byli: prof. Jarosław Ławski (UwB), prof. Swietłana Musijenko (Grodno - Mińsk), doc. dr Inna Lisowska (dziekan Wydziału Filologicznego w Grodnie), doc. dr Sviatlana Honchar

* Łukasz Zabielski - dr, literaturoznawca, edytor XIX-wiecznych tekstów źródłowych; kierownik Działu Naukowego Książnicy Podlaskiej im. Łukasza Górnickiego w Białymstoku. Autor monografii: Meandry antyromantyczności. Kajetan Koźmian i romantycy polscy (Kraków 2015) oraz Kajetan Koźmian spoza kanonu. Studia i szkice historycznoliterackie (Białystok 2018).

1 Konferencję przygotował ten sam zespół, kierowany przez prof. Swietłanę Musijenko i prof. Jarosława Ławskiego, który zorganizował wcześniej konferencje o Elizie Orzeszkowej, Adamie Mickiewiczu. Por. J. Ławski, Międzynarodowa Konferencja Naukowa: „Białorusko-polskie stosunki literackie. Problemy Imagologii (Interpretacje Choriewowskie), Mińsk, 11.X.2015, „Bibliotekarz Podlaski” 1/2015; A. Kołodziejczak, Międzynarodowa Polsko-Bia- 
(kierownik Katedry Języków Obcych) i doc. dr Helena Nielepko (Katedra Języka Rosyjskiego jako Obcego, Grodno).

Gości Konferencji powitali 31 maja na Uniwersytecie Grodzieńskim: dziekan doc. dr Inna Lisowska i prof. Swietłana Musijenko ze strony białoruskiej oraz dr hab. Anna Janicka, prof. UwB ze strony polskiej (w zastępstwie prof. Jarosława Ławskiego, któremu nie wydano na czas wizy, jakoby z powodu niedostarczenia z Grodna jego zaproszenia).

W czasie pierwszego dnia Konferencji występowali na przemian polscy i białoruscy goście; wśród nich: Olga Zakolska i Piotr Bordzoł z IBL PAN („Biuletyn Polonistyczny” a współczesne badania literackie), dr hab. Anna Kieżuń, prof. UwB (Mickiewicz i inni romantycy w ujęciu Mariana Zdziechowskiego - komparatysty. Wokół tomu „Mesjaniści i słowianofile”), dr Lukasz Zabielski z Książnicy Podlaskiej (Stefana Witwickiego problemy ze „Wschodem” polskich romantyków), dr Barbara Olech z UwB (Leonard Podhorski-Okołów - piewca Mickiewicza i ziemi białoruskiej), dr hab. Ewa Hoffmann-Piotrowska z UW (Któż zrozumie słowo „konstytucja”. Czy Mickiewicz odsakralizowat w prelekcjach paryskich zryw dekabrystów?), dr Paweł Wojciechowski z UwB (Pejzaże i diagnozy. Twórczość literacka generacji romantyków szwedzkich ze spojrzeniem na dorobek Adama Mickiewicza), prof. dr hab. Halina Korbicz z UAM (Iwan Franko i Adam Mickiewicz wybrane problemy recepcji); dr hab. Anna Janicka, prof. UwB (Pożegnanie Romana Zmorskiego, badacza Stowiańszczyzny, na łamach „Przegladu Tygodniowego”), dr hab. Beata Kuryłowicz, prof. UwB (Między stowiańskim Wschodem a Zachodem: o deminutywach $w$,Balladach i romansach” Adama Mickiewicza), a także goszcząca na Uniwersytecie w Białymstoku jako visiting professor dr hab. Corinne Fournier Kiss z Berna w Szwajcarii (Wplyw Mickiewicza na George Sand) ${ }^{2}$.

łoruska Konferencja Naukowa „Przeszłość Imagologii”, Białystok, 13-14 maja 2016 r., „Bibliotekarz Podlaski” 1/2016; A. Janicka, Międzynarodowa Konferencja Naukowa „Pamięć kultury: wiecznie żywe słowo Orzeszkowej. W 175. rocznice urodzin Pisarki”, Grodno 27-28 X 2016 roku. Sprawozdanie, „Bibliotekarz Podlaski” 1/2017.

2 Referatów nie wygłosili: prof. Jarosław Ławski (UwB; nie został wpuszczony), doc. dr Mikołaj Chmialnicki (BGU, Mińsk, nie dojechał), doc. dr Aleś Brazgunow (BAN, Mińsk, nie dojechał); doc. dr Iryna Bogdanowicz (BGU, Mińsk, nie dojechała). 
Po obradach, przerywanych dyskusjami, odbyła się prezentacja grodzieńskich i białoruskich wydawnictw naukowych, którą poprowadziły prof. Swietłana Musijenko i prof. Anna Janicka ${ }^{3}$.

Drugi dzień Konferencji poświęcony był zwiedzaniu miejsc związanych z polskimi pisarzami z Grodzieńszczyzny i Nowogródczyzny. Ci goście konferencji z zagranicy, którzy do Grodna przyjechali z wizą turystyczną (obowiązuje tylko w Grodnie oraz okolicach i nie można na jej podstawie udać się do Nowogródka), z satysfakcją zwiedzili grodzieńskie miejsca pamięci powiązane z życiem Elizy Orzeszkowej. Ci zaś, którzy mieli krótko- i długoterminową wizę, udali się wraz z białoruskimi kolegami na wycieczkę śladami Mickiewicza do Nowogródka i nad Świteź. Należy podkreślić troskę, z jaką strona białoruska zajęła się obiema grupami wycieczkowymi. Konferencja ujawniła potencjał polsko-białoruskich badań nad romantyzmem - zresztą nie po raz pierwszy. Odsłoniła także różnice w podejściu do dziedzictwa profesora Collège de France, którego w białoruskim Programie opisano słowami: „Adam Mickiewicz (1798-1855), polski i białoruski poeta, publicysta, dramaturg, eseista, thumacz i pisarz". Nawet otwarci na dialog badacze przyjęli tak silną supozycję białoruskości Mickiewicza jako kontrowersyjną. Konferencja ujawniła też chyba nie tylko komunikacyjne problemy w kontaktach badaczy polskich z ich białoruskimi kolegami. Wypada wierzyć, że są one przejściowe.

Materiały Konferencji ${ }^{4}$ zostaną opublikowane przez Grodzieński Państwowy Uniwersytet im. Janki Kupały. W 2020 roku w Białymstoku zaplanowano kolejne tego typu międzynarodowe spotkanie badaczy twórczości największego polskiego poety Adama Mickiewicza. Oby przebiegło w atmosferze zaufania.

3 Zaprezentowano m. in. tomy: Horevskie čtenia. Vypusk 3, red. S. Musijenko, Grodno 2019; Eliza Orzeszkowa. Pamięć kultury. Studia i głosy, red. J. Ławski, S. Musijenko, Białystok-Grodno 2019; „Bibliotekarz Podlaski” 2/2018: numer monograficzny Franciszek Skaryna; O. Svitelska, O tvorčestve Teodora Parnickiego, Grodno 2019.

4 W białoruskich materiałach konferencyjnych ze względów niezrozumiałych dla obcokrajowców używa się zamiast formy „konferencja międzynarodowa” formuły „międzynarodowy naukowy okrągły stół”. Konferencja spełniała wszelkie warunki międzynarodowości (w ujęciu kryteriów polskich): 11 spośród 26 uczestników pochodziło z ośrodków polskich (Białystok, Warszawa, Poznań) i szwajcarskich (Berno). 